\title{
EFEKTIFITAS PERATURAN DAERAH NOMOR 4 TAHUN 2016 ( Studi Tentang Perlindungan Dan Pemberdayaan Petani di Desa Pelem Kecamatan Campurdarat Kabupaten Tulungagung )
}

\author{
Nunun Nurhajati \\ nununnurhajati@gmail.com \\ Nur Umi Khasanah \\ umikasanah918@gmail.com
}

\begin{abstract}
ABSTRAK
Pertanian merupakan sektor strategis yang sekaligus sektor yang paling banyak menyerap tenaga kerja dan berbasis pedesaan. Era baru pertanian kedepan menghendaki orientasi pada pencapaian nilai tamah, pendapatan, serta kesejahteraan petani sebagai acuan utama dalam pembangunan pertanian. Petani sebagai pelaku utama pembangunan pertanian tentu memiliki berbagai masalah . Masalah ini sering menghambat petani untuk mengembangkan usaha taninya . Masalah yang dihadapi petani ini juga merupakan masalah dasar yang harus diselesaikan untuk melakukan pembangunan pertanian .

Karena banyaknya petani di Tulungagung yang mengalami masalah , pemerintah Kabupaten Tulungagung membuat Peraturan Daerah Kabupaten Tulungagung Nomor 4 Tahun 2016 tentang perlindungan dan pemberdayaan petani. Latar belakang ditetapkanya peraturan daerah tersebut ialah adanya kecenderungan meningkatnya perubahan iklim, gejolak ekonomi global, kerawanan terhadap bencana alam dan resiko gagal usaha, serta adanya sistem pasar yang tidak transparan dan tidak berpihak kepada petani .

Penelitian ini menggunakan jenis penelitian deskriptif kualitatif dengan tujuan untuk bisa memberikan gambaran secara menyeluruh mengenai perlindungan dan pemberdayaan petani melalui Peraturan Daerah Kabupaten Tulungagung Nomor 4 Tahun 2016 . Fokus peneitiannya adalah tentang efektifitas Perda nomor 4 Tahun 2016 Kabupaten Tulungagung dan Faktor apa saja yang menjadi pendorong dan penghambatnya .
\end{abstract}

Kata Kunci : Efektifitas, perlindungan, dan pemberdayaan petani . 


\section{ABSTRACT}

Agriculture is a strategic sector which is also the sector that absorbs the most labor and is rural based. The new era of agriculture in the future requires orientation on achieving suave value, income, and welfare of farmers as the main reference in agricultural development. Farmers as the main actors in agricultural development certainly have various problems. This problem often prevents farmers from developing their farming businesses. The problem faced by farmers is also a basic problem that must be solved to carry out agricultural development .

Due to the large number of farmers in Tulungagung who are experiencing problems, the government of Tulungagung District has enacted the Regional Regulation of Tulungagung Regency Number 4 of 2016 concerning the protection and empowerment of farmers. The background to the enactment of these regional regulations is the tendency of increasing climate change, global economic turmoil, vulnerability to natural disasters and the risk of business failure, as well as the existence of a market system that is not transparent and does not favor farmers .

This study uses descriptive qualitative research with the aim to be able to provide a comprehensive picture of the protection and empowerment of farmers through Tulungagung District Regulation Number 4 Year 2016. The focus of the research is on the effectiveness of Perda number 4 Year 2016 Tulungagung Regency and what factors are driving and the obstacle .

\section{Keywords: Effectiveness, protection, and empowerment of farmers}

\section{PENDAHULUAN}

\section{Latar belakang}

Secara umum posisi sektor pertanian dalam perekonomian nasional mempunyai fungsi ganda . Pertama, mengemban fungsi ekonomi guna penyediaan pangan dan kesempatan kerja. Kedua, fungsi sosial yang berkaitan dengan pemeliharaan masyarakat pedesaan sebagai penyangga budaya bangsa . Ketiga, fungsi ekologi guna perlindungan lingkungan hidup , konservasi lahan, dan cadangan sumber air .

Petani sebagai pelaku utama pembangunan pertanian tentu memiliki berbagai masalah. Masalah ini sering menghambat petani untuk mengembangkan usaha taninya .
Masalah yang dihadapi petani ini juga merupakan masalah dasar yang harus diselesaikan untuk melakukan pembangunan pertanian .

Berikut adalah berbagai masalah petani Indonesia yang perlu diperhatikan . (1) Permodalan terbatas, permodalan sering menjadi masalah ketika petani akan memulai usaha taninya. Modal menjadi masalah karena petani tidak selalu sukses dalam proses budidaya. Sifat hasil pertanian yang lebih tergantung kea lam membuat hasil panen tidak menentu. Berdasarkan hasil survei susenas tahun 2016, hanya 15\% petani Indonesia yang mengakses kredit untuk modal di bank. Petani lebih memilih untuk kredit di lembaga 
nonbank karena prosedurnya yang gampang walaupun dengan suku bunga yang lebih tinggi. Tentu ini sangat merugikan petani . (2) Harga produk tidak stabil, sifat hasil pertanian adalah musiman, yang berarti produk tersebut akan memiliki jumlah yang cukup pada waktu tertentu saja. Misalnya, pada musim panen padi akan melimpahnya pasokan beras, namun pada musim paceklik pasokanya sangat terbatas. Sifat ini tentu sangat mempengaruhi harga produk pertanian yang dihasilkan petani . (3) Penguasaan lahan sempit, salah satu masalah yang terus menghantui pembangunan petani di Indonesia adalah sempitnya penguasaan lahan. Dengan lahan garapan sempit tentu petani juga akan mendapat penghasilan terbatas dan membuat tingkat kesejahteraannya di bawah . (4) Kelangkaan sarana produksi pertanian, masalah kelangkaan sarana produksi pertanian sering dihadapi petani. Padahal sarana produksi pertanian disini berperan sebagai input usaha tani yang dilakukan petani . Sulitnya untuk mendapatkan input ini tentu menjadi masalah karena mampu menghambat kelancaran usaha tani. (Arinda, diakses pada tanggal 09 april 2019) .

Begitu pula para petani di Tulungagung yang kerap mengalami gagal panen akibat cuaca tidak menentu. Akibat hujan deras yang melanda sebagian wilayah di Kabupaten Tulungagung, membuat tanaman padi roboh dan terendam air. Akibatnya, petani terpaksa memanen padi lebih awal. Selain karena terkena banjir, petani di Tulungagung juga sering mengalami gagal panen akibat hama wereng . Puluhan hektar tanaman padi di sejumlah wilayah di Kabupaten Tulungagung gagal panen atau mengalami penurunan produksi akibat bulir padi kosong dampak dari serangan hama wereng. (Rohmah Ermawati, diakses pada tanggal 09 april 2019) .

Karena banyaknya petani di Tulungagung yang mengalami masalah, pemerintah Kabupaten Tulungagung membuat Peraturan Daerah Kabupaten Tulungagung Nomor 4 Tahun 2016 tentang perlindungan dan pemberdayaan petani. Latar belakang ditetapkanya peraturan daerah tersebut ialah adanya kecenderungan meningkatnya perubahan iklim, gejolak ekonomi global, kerawanan terhadap bencana alam dan resiko gagal usaha, serta adanya sistem pasar yang tidak transparan dan tidak berpihak kepada petani, maka diperlukan perlindungan dan pemberdayaan petani (Peraturan 


\begin{tabular}{lccc} 
Daerah & \multicolumn{2}{c}{ Kabupaten } & Tulungagung \\
Nomor 4 & Tahun & 2016 tentang \\
perlindungan & dan & pemberdayaan \\
petani) & & &
\end{tabular}

Perlindungan

dan

pemberdayaan merupakan segala usaha untuk melindungi dari permasalahan atau kesulitan dan segala upaya untuk meningkatkan kemampuan dalam melakukan usahanya. Hal ini sebenarnya dilakukan agar permasalahan petani dapat diselesaikan, akan tetapi pada kenyataanya Peraturan Daerah Kabupaten Tulungagung Nomor 4 Tahun 2016 tentang perlindungan dan pemberdayaan petani lemah dalam implementasinya di masyarakat. Buktinya masih banyak petani yang mengalami permasalahan kerugian dikarenakan gagal panen, sulitnya mendapatkan permodalan dan tidak stabilnya harga .

Kerugian akibat gagal panen, sulitnya mendapatkan permodalan dan tidak stabilnya harga yang saat ini merupakan permasalahan yang cukup membuat para petani resah, yang dirasakan dalam bentuk banyaknya petani yang merugi. Seperti yang terjadi di Desa Pelem Kecamatan Campurdarat

Kabupaten

Tulungagung .

Peneliti menemukan di desa ini banyak petani yang merugi akibat sering terjadinya banjir saat musim hujan akibat pendangkalan sungai yang bermuara di terowongan neyama, kesulitan mendapatkan pasokan air saat musim kemarau dan didukung dengan masih adanya saluran irigasi yang mengalami kerusakan, serta belum adanya lembaga penyedia fasilitas pembiayaan dan permodalan untuk usaha tani .

\section{Rumusan Masalah}

Berdasarkan

pada permasalahan diatas maka perumusan masalah yang dapat dirumuskan oleh penulis adalah :

1. Bagaimana efektifitas Peraturan Daerah Kabupaten Tulungagung Nomor 4 Tahun 2016 di Desa Pelem?

2. Faktor apa sajakah yang menjadi pendorong dan penghambat efektifitas Peraturan Daerah Kabupaten Tulungagung Nomor 4 Tahun 2016 di Desa Pelem?

\section{Tujuan Penelitian}

1. Untuk mengetahui, mendeskripsikan dan menganalisa efektifitas Peraturan Daerah Kabupaten Tulungagung Nomor 4 Tahun 2016 di Desa Pelem.

2. Untuk mengetahui, mendeskripsikan dan menganalisa faktor apa sajakah yang menjadi 
pendorong dan penghambat efektifitas Peraturan Daerah Kabupaten Tulungagung Nomor 4 Tahun 2016 di Desa Pelem.

\section{TINJAUAN PUSTAKA}

\section{A. Pemberdayaan}

1. Pengertian Pemberdayaan

Pemberdayaa adalah suatu kegiatan yang berkesinambungan, dinamis, secara sinergis mendorong keterlibatan semua potensi yang ada secara evolutif dengan keterlibatan semua potensi (Suhendra, 2006). Dari pengertian tersebut dapat dikatakan bahwa elemen penting dari pemberdayaan adalah partisipasi . Partisipasi merupakan proses aktif, inisiatif diambil oleh masyarakat sendiri, dibimbing oleh cara berfikir mereka sendiri dengan menggunakan sarana dan proses (lembaga dan mekanisme) mereka dapat menegaskan kontrol secara efektif. Terdapat berbagai macam definisi pemberdayaan, antara lain:

a. Pemberdayaan adalah meningkatkan kekuasaan atas mereka yang kurang beruntung (Suhendra, 2006:77) .

b. Secara konseptual pemberdayaan atau pemerkuasaan (empowerment) berasal dari kata power atau (kekuasaan atau keberdayaan) . Karena ide utama pemberdayaan bersentuhan dengan kemampuan untuk membuatorang lain melakukan apa yang kita inginkan, terlepas dari keinginan dan minat mereka (Edi Suharto, 2005:57) .

Beragam definisi pemberdayaan mejelaskan bahwa pemberdayaan adalah sebuah proses dan tujuan. Sebagai proses, pemberdayaan adalah serangkaian kegiatan untuk memperkuat kekuasaan atau keberdayaan kelompok lemah dan masyarakat, termasuk individuindividu yang mengalami masalah kemiskinan . Pemberdayaan merupakan suatu usaha atau upaya yang dilakukan dalam rangka mengembangkan kemampuan dan kemandirian individu atau masyarakat dalam memenuhi kebutuhanya. Masyarakat dapat tahu potensi dan permasalahan yang dihadapinya dan mampu menyelesaikanya (Tantan Hermansyah dkk, 2009:31).

2. Pemberdayaan Petani

Pemberdayaan petani adalah segala upaya untuk meningkatkan kemampuan petani untuk melaksanakan usaha tani yang lebih baik melalui pendidikan dan 
pelatihan, penyuluhan dan pendampingan, pengembangan sistem dan sarana hasil pertanian, konsolidasi dan jaminan luasan lahan pertanian, kemudian akses ilmu pengetahuan, teknologi dan informasi, serta penguatan kelembagaan petani . kelembagaan petani merupakan lembaga yang tumbuh kembang dari, oleh dan untuk petani guna memperkuat kerjasama dalam memperjuangkan kepentingan petani dalam bentuk kelompok tani dan gabungan kelompok tani. Selain itu, kelompok tani dengan lembaga petani mempunyai peran penting dan strategi dalam pertumbuhan ekonomi di wilayah pedesaan (Undang-Undang Nomor 19 Tahun 2013 tentang perlindungan dan pemberdayaan petani).

\section{B. Efektifitas}

Efektifitas

keaktifan, daya

kesesuaian dalam suatu kegiatan orang yang melaksanakan tugas dengan sasaran yang dituju. Efektifitas pada dasarnya menunjukkan pada tarif tercapainya hasil, sering atau senantiasa dikaitkan dengan pengertian efisien, meskipun sebenarnya ada perbedaan diantara keduanya. Efektifitas menekankan pada hasil yang dicapai, sedangkan efisien lebih melihat pada bagaimana cara mencapai hasil yang dicapai itu dengan membandingkan antara input dengan outputnya (Siagaan, 2001:24) .

Efektifitas adalah pemanfaatan sumber daya, sarana dan prasarana dalam jumlah tertentu yang secara sadar ditetapkan sebelumnya untuk menghasilkan sejumlah barang atas jasa kegiatan yang dijalankannya (Sondang dalam Othenk 2008) .

Efektifitas menunjukkan keberhasilan dari segi tercapai tidaknya sasaran yang telah ditetapkan. Jika hasil kegiatan semakin mendekati sasaran, berarti makin tinggi efektifitasnya .

Menurut Campbell J.P. dalam Starawaji (2009) bahwa terdapat cara pengukuran efektifitas secara umum dan yang paling menonjol adalah sebagai berikut :

1. Keberhasilan program

Efektifitas program dapat dijalankan dengan kemampuan operasional dalam melaksanakan program- program kerja yang sesuai dengan tujuan yang telah ditetapkan sebelumnya. Keberhasilan program dapat di tinjau dari proses dan mekanisme suatu kegiatan dilakukan dilapangan . 
2. Keberhasilan sasaran

$\begin{aligned} & \text { Efektifitas ditinjau dari sudut } \\ & \text { pencapaian tujuan dengan }\end{aligned}$
memusatkan perhatian terhadap
aspek output, artinya efektifitas
dapat diukur dengan seberapa jauh
tingakat output dalam kebijakan dan
prosedur dari organisasi untuk
mencapai tujuan yang telah
ditetapkan .

3. Kepuasan terhadap program

Kepuasan merupakan kriteria efektifitas yang mengacu pada keberhasilan program dalam memenuhi kebutuhan pengguna. Kepuasan dirasakan oleh para pengguna terhadap kualitas produk atau jasa yang dihasilkan .

4. Tingakat input dan output

$$
\text { Pada efektifitas tingkat input }
$$
dan output dapat dilihat dari perbandingan antara masukan (input) dengan output (output). Jika output lebih besar dari input maka dapat dikatakan efisien dan sebaliknya jika input lebih besar dari output maka dapat dikatakan tidak efisien .

5. Pencapaian tujuan menyeluruh Sejauh mana organisasi melaksanakan tugasnya untuk mencapai tujuan. Dalam hal ini merupakan penilaian umum dengan sebanyak mungkin kriteria tunggal dan menghasilkan penilaian umum efektifitas organisasi .

$$
\text { Berdasarkan beberapa }
$$

uraian di atas dapat disimpulkan bahwa efektifitas adalah suatu keadaan yang menunjukkan sejauh mana rencana dapat tercapai. Semakin banyak rencana yang dapat dicapai, semakin efektif pula kegiatan tersebut, sehingga kata efektifitas dapat juga diartikan sebagai tngkat keberhasilan yang dapat dicapai .

\section{Desa}

Desa adalah kesatuan masyarakat hukum yang memiliki batas wilayah yang berwenang untuk mengatur dan mengurus urusan pemerintahan , kepentingan masyarakat setempat berdasarkan prakarsa masyarakat, hak asal usul, dan/atau hak tradisional yang diakui dan dihormati dalam sistem pemerintahan Negara Kesatuan Republik Indonesia. Dari situlah terbukti bahwa kesatuan masyarakat hukum, yakni warga desa yang tinggal dalam suatu lokasi yang mana memiliki hak atau wewenang untuk melakukan atau menjalankan pemerintahanya untuk kepentingan warga yang tinggal dalam kawasan desa tersebut (Undang-Undang Nomor 6 Tahun 2014 tentang Desa) . 
Dari pengertian beberapa tentang desa tersebut di atas sangat jelas sekali bahwa desa merupakan self community yaitu komunitas yang mengatur dirinya sendiri. Dengan pemahaman bahwa desa memiliki kewenangan untuk mengurus dan mengatur kepentingan masyarakatnya sesuai dengan kondisi dan sosial budaya setempat, maka posisi desa yang memiliki otonomi asli sangat strategis sehingga memerlukan perhatian yang seimbang terhadap penyelenggaraan otonomi daerah. Karena dengan otonomi desa yang kuat akan mempengaruhi secara signifikan perwujudan otonomi daerah

\section{Petani}

\section{Pengertian Petani}

$\begin{array}{lr}\text { Menurut } & \text { Rodjak } \\ \text { (2006), petani sebagai } & \text { unsur } \\ \text { usaha tani memegang peranan } & \text { pemilihan } \\ \text { yang penting dalam } \text { dapat } \\ \text { tanaman atau ternak agar } \\ \text { tumbuh dengan baik, ia berperan } \\ \text { sebagai pengelola usaha } \\ \text { tani. Petani sebagai pengelola } \\ \text { usaha tani berarti harus mengambil } \\ \text { berbagai keputusan di dalam } \\ \text { memanfaatkan lahan yang dimiliki } \\ \text { atau disewa dari petani lainya } \\ \text { untuk kesejahteraan hidup } \\ \text { keluarganya Petani yang dimaksud } \\ \text { dalam hal ini adalah orang yang }\end{array}$

bercocok tanam hasil bumi atau memelihara ternak dengan tujuan untuk memproleh kehidupan dari kegiatan itu. Dilihat dari hubunganya dengan lahan yang diusahakan maka petani dapat dibedakan atas :

1) Petani pemilik penggarap ialah petani yang memiliki lahan usaha sendiri serta lahannya tersebut diusahakan atau digarap sendiri dan status lahanya disebut lahan milik .

2) Petani penyewa ialah petani yang menggarap tanah orang lain atau petani lain dengan status sewa. Alasan pemilik lahan menyewakan lahan miliknya karena membutuhkan uang tunai dalam jumlah yang cukup besar dalam waktu singkat, atau lahan yang dimilikinya itu terlalu jauh dari tempat tinggalnya. Besarnya nilai sewa lahan biasanya ada hubungan dengan tingkat produktivitas lahan usaha yang bersangkutan, makin tinggi produktivitas lahan tersebut makin tinggi pula nilai sewanya .

3) Petani penyakap ( penggarap) ialah petani yang menggarap tanah milik petani lain dengan sistem bagi hasil . 
4) Petani penggadai adalah petani yang menggarap lahan tani orang lain denga sistem gadai . Adanya petani yang menggadaikan lahan miliknya, karena petani pemilik lahan tersebut membutuhkan uang tunai yang cukup besar dalam waktu mendesak, tanah miliknya tersebut tidak mau pindah ke tangan orang lain secara mutlak .

5) Buruh tani ialah petani pemilik lahan atau tidak memiliki lahan usaha tani sendiri yang biasa bekerja di lahan usaha tani petani pemilik atau penyewa dengan mendapat upah, berupa uang atau barang hasil usaha tani, seperti beras atau makanan lainya .

Menurut Wahyudin (2005:39) golongan petani di bagi menjadi tiga yaitu :

1. Petani kaya : yakni petani yang memiliki luas lahan pertanian 2 , 5 ha lebih.

2. Petani sedang : petani yang memiliki luas lahan pertanian 1 sampai 2,5 ha .

3. Petani miskin : petani yang memiliki luas lahan pertanian kurang dari 1 ha .

\section{Usaha Tani}

Usaha tani merupakan suatu jalinan yang kompleks yang terdiri dari tanah, tumbuhan, hewan, peralatan, tenaga kerja, input dan pengaruh pengaruh lingkungan yang dikelola oleh seseorang yang disebut petani sesuai dengan kemampuanya dan aspirasinya (Reintjntjes, 2004) . Faktor-faktor yang bekerja dalam usaha tani adalah faktor alam, tenaga, modal. Faktor alam dapat dibedakan menjadi dua yaitu faktor tanah dan lingkugan alam sekitarnya seperti ketersediaan air, suhu dan lain- lain.

Usaha tani merupakan ilmu yang mempelajari bagaikan mengalokasikan sumber daya yang dimiliki petani agar berjalan secara efektif dan efisien dan memanfaatkan sumber daya tersebut agar memperoleh keuntungan yang setinggi-tingginya (Soekarwati, 2011) .

\section{Komoditas Pertanian}

Menurut Djamali (2000), peratanian dalam arti luas adalah suatu sektor yang mengemukakan berbagai hal tentang biologi di bumi baik nabati maupun hewani selain manusia yang diperuntukan bagi kelangsungan hidup manusia. Ada beberapa macam komoditas pertanian yang terbagi menjadi 3 kelompok yaitu komoditas pangan, komoditas perkebunan, dan komoditas hortikultura . Budidaya pertanian 
dapat menghasilkan komoditas tertentu yang dapat berupa komoditas pangan maupun non pangan . Komoditas pangan dimanfaatkan manusia untuk kelangsunganbiologisnya,sedangkan non pangan dimanfaatkan untuk keperluan penunjang. Komoditas pangan nabati dapat dikelompokan berdasarkan

beberapa kriteria/karakteristik,sepertikarakteris tik agronomis, fisiologis, dan fisikokimia atau gizi. Kelompok komoditas pertanian ini adalah serealia, kacang- kacangan, ubiubian, sayuran dan buahbuahan . Pada komoditas perkebunan, perkebunan sendiri ialah segala kegiatan yang bertujuan untuk memproduksikan tanaman tertentu dengan nilai ekonomi tertentu dengan memperhatikan ekosistem, pengolahan, pemasaran, dan jasa hasil tanam tersebut. Tanaman yang ditanampun biasanya tanaman- tanaman yang berukuran besar dengan waktu hidup yang cukup lama/tahunan. Contohnya adalah tanaman kelapa sawit, cengkeh, kakao, karet, kelapa, teh, kopi, dsb. Komoditas holtikultura, holtikultura merupakan budidaya tanaman kebun .

\section{METODE PENELITIAN}

\section{A. Jenis Penelitian}

Metode penelitian yang digunakan oleh peneliti adalah metode penelian kualitatif. Penelitian kualitatif banyak dipergunakan pada ilmu sosial, metode ini menggunakan data yang dinyatakan verbal dan kualifikasinya bersifat teoritis. Pengolahan data dan pengujian hipotesis tidak berdasarkan statistik, melainkan dengan pola berfikir tertentu menurut hukum logika .

\section{B. Pemilihan Lokasi dan Situs Penelitian \\ Tempat atau lokasi penelitian} dalam studi kasus ini, penulis memilih Kabupaten Tulungagung . Situs penelitian yang dipilih oleh penulis berdasarkan tema yang dipilih adalah Desa Pelem .

\section{Sumber Data}

Menurut Lofland dan Lofland (1884:47) dalam Moleong (2002) mengatakan bahwa sumber data utama dalam penelitian kualitatif ialah kata kata, tindakan dan selebihnya adalah data tambahan seperti dokumen dan sebagainya. Yang mana nantinya jenis datanya dibagibagi lagi ke dalam kata-kata dan tindakan, sumber data tertulis, foto, dan statistik. Menurut Marzuki (2005), 
data dapat dibedakan berdasarkan sumbernya ada 2 , yaitu:

1. Data Primer

Data primer adalah data
yang diperoleh langsung dari
sumbernya, diamati dan dicatat
untuk pertama kalinya. Data
tersebut menjadi data sekunder jika
digunakan oleh orang yang tidak
berhubungan langsung dengan
penelitian yang bersangkutan
Data primer diperoleh dari
wawancara yang dilakukan
dari: kepala desa pelem,
masyarakat desa pelem yang
berprofesi sebagai petani dan
anggota kelompok tani desa
pelem .

2. Data Sekunder

Data sekunder adalah data yang bukan diusahakan sendiri pengumpulannya oleh peneliti . Data sekunder yang akan diambil oleh peneliti adalah data yang diambil dari dokumen-dokumen dari desa , dokumen dari kelompok tani desa pelem, surat kabar dan catatancatatan dari instansi terkait .

\section{HASIL PENELITIAN DAN PEMBAHASAN}

\section{A. Hasil Penelitian}

Desa Pelem adalah salah satu desa di Kecamatan Campurdarat Kabupaten Tulungagung. Wilayah perbatasan dengan Desa Wates disebelah utara, perhutani disebelah selatan, Desa Pojok disebelah timur dan Desa Campurdarat disebelah barat. Desa Pelem merupakan desa yang terletak di Kecamatan Campurdarat dengan luas wilayah $539.135 \mathrm{Ha}$ yang terdiri dari:

a. Tanah pemukiman/perumahan seluas : 176,543 Ha

b. Tanah sawah yang terdiri dari :

1) Irigasi setengah teknis : 13,014 $\mathrm{Ha}$

2) Irigasi teknis : $26.000 \mathrm{Ha}$

3) Irigasi hujan : $179,005 \mathrm{Ha}$

c. Tanah kering :

1) Pekarangan : $196.000 \mathrm{Ha}$

2) Tegal/ladang : $23.150 \mathrm{Ha}$

d. Tanah hutan seluas : $27,150 \mathrm{Ha}$

e. Tanah perkebunan : 5, $595 \mathrm{Ha}$

\section{Struktur Organisasi Desa Pelem}

1. Kepala Desa: Mujialam

2. Sekretaris Desa: Hariyadi

3. Kepala Dusun Bangak:Samsul

4. Kepala Dusun Sumberjo: Mahfud

5. Kepala Dusun Bangak: Samsul

6. Kepala Dusun Jambu:Suyono

7. Kepala Dusun Pelem: Sukir

8. Kaur Pemerintahan: Suwarno

9. Kaur Pembangunan: Padelan

10. Kaur Kesra: H. Suparlan

11. Kaur Keuangan: Sumaryono

12. Kaur Umum: Aguswandi

13. Staf Umum: Siswandi 
Mata pencaharian penduduk Desa Pelem itu mayoritas adalah petani, yang mana hal tersebut sesuai dengan data yang didapatkan peneliti dari Desa Pelem :

\section{Tabel 1}

Jenis mata pencaharian penduduk DesaPelem

\begin{tabular}{|l|c|}
\hline \multicolumn{1}{|c|}{ Pekerjaan } & Persentase \\
\hline Tani & $63,7 \%$ \\
\hline Buruh tani & $13,2 \%$ \\
\hline Wiraswasta & $11 \%$ \\
\hline Pegawai negeri & $3 \%$ \\
\hline Peternak & $5 \%$ \\
\hline Kuli & $4,1 \%$ \\
\hline
\end{tabular}

(Sumber : Pemerintah Desa Pelem 2019)

Di Desa Pelem terdapat beberapa kelompok tani, yang mana hal tersebut sesuai data yang peneliti peroleh dari Desa Pelem :

1 Kelompok tani bahagia Bapak Mrakih 130 orang

2. Kelompok tani harapan jaya Bapak Sumaji 130 orang

3. Kelompok tani maju Bapak Sugeng 130 orang

\section{B. Efektifitas Peraturan Daerah} Kabupaten Tulungagung Nomor 4 Tahun 2016 di Desa Pelem

Sudah sejak lama masyarakat Desa Pelem yang berprofesi sebagai petani mengalami kesulitan, petani sebagai pelaku utama pembangunan pertanian tentu memiliki berbagai

$\begin{array}{lrr}\text { masalah. Masalah } & \text { ini } & \text { sering } \\ \text { menghambat } & \text { petani } & \text { untuk } \\ \text { mengembangkan } & \text { usaha } & \text { taninya . }\end{array}$
Seperti kerugian gagal panen akibat cuaca yang tidak menentu, yang menyebabkan petani di Desa Pelem mengalami kerugian dan akibatnya mereka harus mengeluarkan biaya ekstra untuk menanam kembali tanaman mereka yang terkena banjir . Seperti yang diungkapkan oleh bapak Suminto warga Dusun Pelem Desa Pelem berikut ini:

"Pas banjir wingi niko tandurane pari podo klelep banyu kabeh, tapi wong kene yo ndak iso nangani amergo banyune duwur. Teko pemerintah yo ndak enek bantuan dompeng kanggo nyedot banyu nang sawah seng klelep banjir. Dadi yo mung di jarne ae mbak. Sak wise banjire sat yo maleh ngolah lahan eneh kanggo di tanduri, dadine ngetokne biaya eneh. Lha piye, lek ndak nandur eneh nggeh bingong, mergo yo olehe sandang pangan ko asile sawah. Sak liyane banjer petani kene yo kangelan banyu pas ketigo, mergo irigasine rusak dadi yo ngge mbanyoni sawah nganggo disele dewe."

Selain musim hujan, petani di Desa Pelem juga sering mengalami kesulitan pada saat kemarau panjang, yang menyebabkan berkurangnya pasokan air. Hal ini didukung dengan masih adanya saluran irigasi sekunder dan saluran 
irigasi tersier yang selain musim hujan, petani di Desa Pelem juga sering mengalami kesulitan pada saat kemarau panjang , yang menyebabkan berkurangnya pasokan air. Hal ini didukung dengan masih adanya saluran irigasi sekunder dan saluran irigasi tersier yang mengalami kerusakanengalami kerusakan.

Selain membangun sistem peringatan dini terhadap dampak perubahan iklim, pemerintah seharusnya melakukan normalisasi sungai yang bermuara di terowongan neyama. Pasalnya, jika saat musim hujan berlangsung air yang datang secara tiba-tiba dengan jumlah besar tidak dapat ditampung oleh sungai yang telah mengalami pendangkalan tersebut dan akhirnya menyebabkan air sungai meluap . Banjir yang terjadi pada maret 2019 lalu menyebabkan petani mengalami gagal panen. Pemberian bantuan bibit padi juga penting untuk petani, guna melakukan proses penanaman kembali pasca banjir .

Pemberian bantuan peralatan pompa air dan pembenahan saluran irigasi juga penting untuk dilakukan . Karena bukan hanya pada musim hujan, petani juga sering mengalami kesulitan saat menghadapi musim kemarau panjang yang menyebabkan berkurangnya pasokan air. Berdasarkan data yang peneliti peroleh dari pemerintah Desa Pelem sebanyak 1.400 meter saluran irigasi sekunder dan 2.975 meter saluran irigasi tersier mengalami kerusakan .

Selain kerugian gagal panen yang disebabkan oleh cuaca yang tidak menentu, petani di Desa Pelem juga sering mengalami kesulitan dalam mendapatkan permodalan untuk mengolah lahan. Hal ini sebagaimana yang dijelaskan oleh bapak Wakiran warga Dusun Jambu Desa Pelem berikut ini :

" kanggo ngragati ngolah lahan, masyarakat kene ijek nganggo dana pribadi mbak. Mboh kuwi golek utang nang bank. Umpomo lek wes panen mengko yo di bayar lunas utange. Tapi seng dadi masalah lek sak umpomo sawahe gagal panen ."

Kondisi semacam ini didukung dengan kurangnya lembaga penyedia fasilitas pembiayaan dan permodalan . Sehingga untuk mendapatkan biaya menggarap sawah, petani di Desa Pelem masih mengandalkan pinjaman dari bank dan dengan bunga yang cukup tinggi . Permodalan merupakan salah satu faktor produksi penting dalam usaha pertanian . Perkembangan suatu usaha tani dipengaruhi ketersediaan modal . Modal sendiri umumnya tidak cukup 
untuk memenuhi kebutuhan suatu usaha. Oleh karena itu, ketersediaan modal dari pihak luar sebagai sumber pembiayaan sangat diperlukan. Pembiayaan dalam pertanian adalah cara mendapatkan dana selain modal sendiri bagi usahatani serta menggunakannya dengansebaik-baiknya . Keberadaan sumber pembiayaan dalam bentuk kredit sangat penting dalam pengembangan produktivitas pada sektor pertanian terutama untuk petani skala kecil. Ketersediaan kredit/pembiayaan yang memadai dapat menciptakan pembentukan modal bagi usaha tani sehingga dapat meningkatkan produksi, pendapatan, dan menciptakan surplus yang dapat digunakan untuk membayar kembali kredit yang diperoleh .

Dalam rangka memberikan fasilitas pembiayaan dan permodalan, Peraturan Daerah Kabupaten Tulungagung Nomor 4 Tahun 2016 tentang perlindungan dan pemberdayaan petani, pada Pasal 38 diatur mengenai:

1) Pemerintah Daerah wajib memfasilitasi pembiayaan dan permodalan bagi usahatani .

2) Fasilitas pembiayaan dan permodalan sebagaimana dimaksud pada ayat (1) dilakukan dengan : a. Pemberian pinjaman modal untuk memiliki dan/ atau memperluas lahan pertanian .

b. Pemberian bantuan penguatan modal begi petani sebagaimana dimaksud dalam pasal 9 ayat (2) .

c. Pemberian bantuan program pertanian

d. Pemberian subsidi bunga kredit program dan/atau imbal jasa penjamin; dan/atau

e. Pemanfaatan dana tanggung jawab sosial perusahaan serta dana program kemitraan dan bina lingkungan .

Berdasarkan Peraturan Daerah Nomor 4 Tahun 2016 tentang perlindungan dan pemberdayaan petani, dalam rangka untuk memberdayakan petani seharusnya Pemerintah Desa membentuk koperasi kelompok tani . Koperasi kelompok tani dapat berfungsi sebagai salah satu cara masyarakat pertanian dalam meningkatkan penghasilan mereka dengan cara meminjam modal kepada koperasi . Dengan meminjam modal, petani mampu mengembangkan hasil pertanian mereka dengan membeli pupuk dan menambah lahan pertanian. Disamping itu petani juga dapat membuka usaha lain seperti beternak dengan menggunakan modal yang telah dipinjam kepada koperasi . Adanya koperasi kelompok 
tani diharapkan bisa membantu petani untuk mendapatkan permodalan dengan bunga yang ringan, jika dibandingkan dengan meminjam modal kepada bank .

Kelompok tani dibentuk dengan harapan agar bisa menjadi wadah dalam kegiatan dibidang pertanian. Adanya tempat untuk belajar bagi petani, yaitu pada saat para petani berkumpul dalam sebuah pertemuan kelompok tani disinilah para petani saling berinteraksi, bertukar informasi dan bertukar pengalaman. Maka dari itu kelompok tani sendiri bisa menjadi wahana tempat belajar bagi para petani. Selanjutnya manfaat yang lain yaitu kelompok tani bisa menjadi suatu wadah atau sarana untuk mewujudkan impian petani dan tujuan bersama anggota kelompok, sudah pasti tujuan akhir dari kelompok tani ialah untuk meningkatkan kesejahteraan anggotanya .

Pemberdayaan

petani

merupakan segala upaya untuk meningkatkan kemampuan petani untuk melaksanakan usaha tani yang lebih baik melalui pendidikan dan pelatihan, penyuluhan dan pendampingan, pengembangansistem dan sarana hasil pertanian, konsolidasi dan jaminan luasan lahan pertanian, kemudahan akses ilmu pengetahuan, teknologi dan informasi, serta penguatan kelembagaan petani . Usaha untuk meningkatkan pemberdayaan petani adalah usaha untuk meningkatkan pembentukan sikap mental melalui sikap mandiri dalam berusaha. Konsep pemberdayaan masyarakat petani secara mendasar berarti menempatkan masyarakat untuk dihimpun dan diperkuat sehingga dapat berperan sebagai lokomotif bagi kemajuan ekonomi .

Pemberdayaan kelompok tani merupakan sebuah model pemberdayaan yang arah pembangunan berpihak pada rakyat . Kelompok tani pada dasarnya sebagai pelaku utama pembangunan di pedesaan. Kelompok tani dapat memainkan peran tunggal maupun ganda, seperti penyediaan input usaha tani, penyediaan air irigasi, penyediaan modal, penyediaan informasi, serta pemasaran hasil secara kolektif. Peran kelompok tani merupakan gambaran tentang kegiatan-kegiatan kelompok tani yang dikelola berdasarkan persetujuan anggotanya .

\section{Adanya PERDA Nomor 4} Tahun 2016 tentang perlindungan dan pemberdayaan petani sebenarnya sudah disosialisasikan oleh Pemerintah Desa Pelem kepada masyarakat. Untuk prasarana 
penunjang bagi petani, Pemerintah Desa Pelem membangun jalan sepanjang 390 meter menggunakan dana desa untuk mempermudah akses petani menuju area persawahan. Dari hasil pantauan di lapangan, diketahui bahwa sosialisasi tentang adanya PERDA tersebut masih belum efektif. Hal ini dikarenakan kurangnya fasilitas kebijakan, PERDA Nomor 4 Tahun 2016 tentang perlindungan dan pemberdayaan petani hanya sekedar disahkan dan dengan sosialisasi yang minim, pengadaan poster dan baliho hanya berada di beberapa titik ramai di Tulungagung dan tidak sampai ke desa-desa .

\section{Faktor Pendorong dan Penghambat}

\section{Faktor Yang Menjadi Pendorong}

a. Program pemberian benih padi dan jagung. Diberikan satu tahun sekali sesuai dengan kebutuhan petani, dengan maksimal luas lahan $2 \mathrm{Ha}$.

b. Program subsidi pupuk, yaitu pupuk organik dan pupuk urea, dengan harga pupuk organik $R p$ $22.000 / 50 \mathrm{~kg}$ dan pupuk urea Rp $100.000 / 50 \mathrm{~kg}$.

c. Pembangunan akses jalan menuju area persawahan oleh Pemerintah Desa sepanjang 390 meter dengan menggunakan dana desa .

\section{Faktor Yang Menjadi Penghambat}

a. Kurangnya sistem peringatan dini dan penanganan dampak perubahan iklim, sebagaimana dimaksud dalam pasal 5 ayat (2) huruf $d$.

Sektor pertanian merupakan sektor yang paling terdampak terhadap perubahan iklim baik itu banjir maupun kekeringan . Pada beberapa tahun terakhir telah terjadi pergeseran musim dan puncak hujan, dan perubahan musim ini sangat mengganggu pola tanam dan produktivitas pertanian. Pada dasarnya

cuaca/iklim dimanfaatkan untuk membuat perencanaan, yakin perencanaan stratejik dan perencanaan operasional serta pengendalian pelaksanaan kegiatan pertanian. Petani di Desa Pelem masih menggunakan cara tradisional dalam memperkirakan cuaca. Sistem peringatan dini tehadap dampak perubahan iklim berfungsi sebagai informasi bagi petani untuk pertimbangan dalam membuat rencana atau pola kegiatan pertanian pertanian . Diperlukanya sosialisasi dan informasi yang tepat tentang perubahan iklim, 
dampak dan adaptasinya kepada masyarakat, khususnya petani .

b. Pendangkalan sungai yang bermuara di terowongan neyama. Bencana banjir yang terjadi di Desa Pelem dipicu hujan sepanjang hari mulai rabu hingga kamis pagi, diperkirakan seluas 45 hektar lahan pertanian di Desa Pelem terendam banjir dan dipastikan gagal panen, sedangkan total kerugian diperkirakan hingga ratusan juta . Hal ini disebabkan karena sungai yang bermuara di terowongan neyama mengalami pendangkalan. Air yang datang secara tiba- tiba dengan jumlah besar menyebabkan sungai yang telah mengalami pendangkalan tidak mampu memuat air untuk dialirkan ke laut .

c. Masih adanya saluran irigasi yang mengalami kerusakan . Selain musim hujan, petani di Desa Pelem juga sering mengalami kesulitan pada saat musim kemarau panjang, yang menyebabkan berkurangnya pasokan air. Hal ini didukung dengan masih adanya saluran irigasi sekunder sepanjang 1.400 meter dan saluran irigasi tersier sepanjang
2.975 meter yang mengalami kerusakan .

d. Belum adanya lembaga koperasi kelompok tani. Untuk membiayai usaha tani masyarakat desa pelem masih menggunakan dana pribadi atau dana yang diperoleh dari pinjaman di bank. Pentingnya lembaga koperasi kelompok tani sebagai salah satu cara masyarakat pertanian dalam meningkatkan penghasilan mereka dengan cara meminjam modal kepada koperasi . Dengan meminjam modal, petani

mampu mengembangkan hasil pertanian mereka dengan membeli pupuk dan menambah lahan pertanian. Disamping itu, petani juga dapat membuka usaha lahan seperti beternak menggunakan modal yang telah dipinjam kepada koperasi . Adanya koperasi kelompok tani diharapkan bisa membantu petani untuk mendapatkan permodalan dengan bunga yang ringan. Mengingat di Desa Pelem terdapat 5 Dusun, maka seharusnya di setiap dusun minimal mempunyai satu 


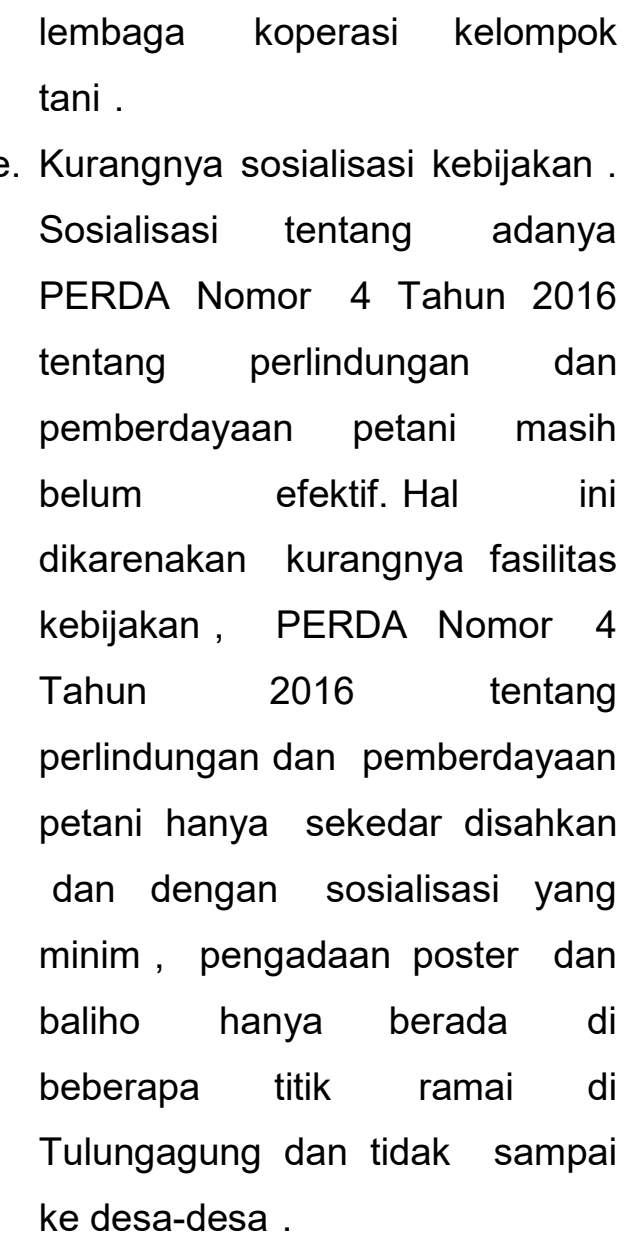

\section{KESIMPULAN}

\section{Berdasarkan hasil penelitian maka dapat diketahui efektifitas} Peraturan Daerah Kabupaten Tulungagung Nomor 4 Tahun 2016 di Desa PelemBahwasannya Peraturan Daerah Kabupaten Tulungaagung Nomor 4 Tahun 2016 di Desa Pelem tidak efektif. Ketidak efektifitasan PERDA tersebut disebabkan oleh beberapa faktor-foktor :

a. Keberhasilan program

Efektifitas program dapat dijalankan dengan kemampuan operasioanal dalam melaksanakan program-program kerja yang sesuai dengan tujuan yang telah ditetapkan sebelumnya . Keberhasilan program dapat di tinjau dari proses dan mekanisme suatu kegiatan dilakukan dilapangan. PERDA Nomor 4 Tahun 2016 tentang perlindungan dan pemberdayaan petani, Pasal 5 ayat (2) huruf $d$, belum memberikan kontribusi untuk petani dalam rangka memperoleh informasi cuaca dan iklim guna menunjang petani dalam mempertimbangkan membuat perencanaan atau pola kegiatan pertanian .

b. Keberhasilan sasaran

Efektifitas ditinjau dari sudut pencapaian tujuan dengan memusatkan perhatian terhadap aspek output, artinya efektifitas dapat diukur dengan seberapa jauh tingkat output dalam kebijakan dan prosedur dari organisasi untuk mencapai tujuan yang telah ditetapkan. PERDA Nomor 4 Tahun 2016 tentang perlindungan dan pemberdayaan petani dalam pelaksanaanya dilapangan masih ditemui banyak hal yang menghambat proses perlindungan dan pemberdayaan petani . Diantaranya adalah, pendangkalan sungai yang menyebabkan banjir di area 
persawahan pada musim hujan, masih adanya saluran irigasi yang mengalami kerusakan, serta belum adanya lembaga pembiayaan dan permodalan bagi petani .

c. Kepuasan terhadap program

Kepuasan merupakan kriteria efektifitas yang mengacu pada keberhasilan program dalam memenuhi kebutuhan pengguna . Kepuasan dirasakan oleh para pengguna terhadap kualitas produk atau jasa yang dihasilkan. Pengguna dari produk kebijakan PERDA Nomor 4 tahun 2016 adalah petani . Masih banyaknya petani di Desa Pelem yang mengeluhkan kurangnya bantuan untuk mengatasi banjir yang yang melanda area persawahan pada maret 2019 lalu, serta masih adanya kondisi saluran irigasi yang rusak menghambat para petani dalam proses pelaksanaan usaha tani .

\begin{tabular}{lr}
\multicolumn{2}{c}{ Faktor yang menjadi } \\
pendorong dan penghambat \\
efektifitas
\end{tabular}

Kabupaten Tulungagung Nomor 4 Tahun 2016 di Desa Pelem adalah sebagai berikut :

1. Faktor pendorong:

Terdapat 3 (tiga) faktor pendorong diantaranya program pemberian benih jagung dan padi, program subsidi pembelian pupuk dan peralatan pertanian, pembangunan akses jalan menuju ke area persawahan oleh Pemerintah Desa .

2. Faktor penghambat:

Terdapat 5 (lima) faktor penghambat antara lain : kurangnya sistem peringatan dini dan penanganan dampak perubahan iklim sebagaimana dimaksud dalam pasal 5 ayat (2) huruf d, pendangkalan sungai yang bermuara di terowongan neyama yang menyebabkan area persawahan sering terendam banjir saat musim hujan, masih adanya saluran irigasi yang mengalami kerusakan, belum adanya lembaga koperasi kelompok tani, dan kurangnya sosialisasi kebijakan .

\section{B. Saran}

1. Seharusnya pemerintah Kabupaten Tulungagung melakukan koordinasi dengan pihak terkait dan juga pemerintah desa untuk membangun sistem peringatan dini dan penanganan dampak perubahan iklim sebagaimana dimaksud dalam pasal 5 ayat (2) huruf $d$. Sistem peringatan dini terhadap dampak 
perubahan iklim berfungsi sebagai informasi bagi petani untuk pertimbangan dalam membuat rencana atau pola kegiatan pertanian . Diperlukanya sosialisasi informasi yang tepat tentang perubahan iklim, dampak dan adaptasinya kepada masyarakat, khusunya petani .

2. Selain membangun sistem peringatan dini terhadap dampak perubahan iklim, pemerintah seharusnya melakukan normalisasi sungai yang bermuara di terowongan

neyama . Pasalnya, jika saat musim hujan berlangsung air yang datang secara tiba-tiba dengan jumlah besar tidak dapat ditampung oleh sungai yang telah mengalami pendangkalan tersebut dan akhirnya menyebabkan air sungai meluap .

3. Pembenahan saluran irigasi juga penting untuk dilakukan. Karena bukan hanya pada musim hujan, petani juga sering mengalami kesulitan saat menghadapi musim kemarau panjang yang menyebabkan berkurangnya pasokan air. Berdasarkan data yang peneliti peroleh dari pemerintah Desa Pelem sebanyak 1.400 meter saluran irigasi sekunder dan 2.975 meter saluran irigasi tersier mengalami kerusakan .

4. Pemerintah Desa membentuk koperasi kelompok tani. Koperasi kelompok tani dapat berfungsi sebagai salah satu cara masyarakat pertanian dalam meningkatkan penghasilan mereka dengan cara meminjam modal kepada koperasi . Dengan meminjam modal, petani mampu mengembangkan hasil pertanian mereka dengan membeli pupuk dan menambah lahan pertanian. Disamping itu petani juga dapat membuka usaha lain seperti beternak dengan menggunakan modal yang telah dipinjam kepada koperasi . Adanya koperasi kelompok tani diharapkan bisa membantu petani untuk mendapatkan permodalan dengan bunga yang ringan, jika dibandingkan dengan meminjam modal kepada bank .

5. Kurangnya sosialisasi kebijakan . Seharusnya Pemerintah Kabupaten Tulungagung bukan hanya sekedar di sahkan dan dengan sosialisasi yang minim, pengadaan poster dan baliho bukan hanya di titik ramai di Tulungagung akan tetapi juga harus ke desa-desa . 


\section{DAFTAR PUSTAKA}

\section{a. Buku}

AG, Subarsono, 2011, Analisis Kebijakan Publik (Konsep, Teori dan Aplikasi), Pustaka Pelajar, Yogyakarta

Aziz, Ali,2005, Dakwah Pemberdayaan Masyarakat : Paradigma Aksi Metodologi, PT LKSIS Pelangi Nusantara, Yogyakarta.

Djamali, 2000, Manajemen Usaha Tani, Depdiknas, Jakarta.

Harry, Hikmat, 2001, Strategi Pemberdayaan Masyarakat, Humaniora Utama, Press, Bandung.

Hamidi dan Mutik, 2011, Legislatif Drafing, Total Media, Yogyakarta.

Huberman dan Miles dalam Husaini Usman, 2008, Manajemen: Teori, Praktik dan Riset Pendidikan, Bumi Aksara, Jakarta .

Ida, Zurida, 2013, Teknik Penyusunan Peraturan Daerah, Sinar Grafika, Jakarta.

Ismani HP, 1991, Metode Penelitian, bpp-fia Universitas Brawijaya, Malang.

Marzuki, 2005, Metodologi Riset, Ekonesia, Yogyakarta.

Rukiminto, Adi, 2002, PemikiranPemikiran dalam Pembangunan Kesejahteraan Sosial, UI Press, Jakarta.

Reintjnts, 2004, Pertanian Masa Depan, Kanisius, Yogyakarta.
Repley dan Franklin dalam Winarto, 2014, Kebijakan Publik Teori, Proses dan Study Kasus, Media Presindo, Yogyakarta.

Rodjak, 2006, Manajemen Usaha Tani. Jilid II, Pustaka Gratuna, Bandung.

Slamet, 2000, Agricultur, LP-IPB, Bandung.

Sumaryadi, 2005,Perencanaan Pembangunan Daerah Otonomi dan Pemberdayaan Masyarakat, Citar Utama.

Suhendra, 2006, Peran Birokrasi Dalam Pemberdayaan Masyarakat, Alfabeta, Bandung.

Sutrisno, Edi, 2007, Manajemen Sumber Daya Manusia, kencana, Jakarta.

Soekarwati, 2011,IImu Usaha Tani dan Penelitian Untuk Pengembangan Petani Kecil, UI Press, Jakarta.

Suratiyah, 2008, IImu Usaha Tani, Penebar Swadaya, Jakarta.
Sondang, Siagaan, 2001, Manajemen Sumberdaya Manusia, Bumi Aksara, Jakarta.

Suharto, Edi, 2005, Membangun Masyarakat Memberdayakan Rakyat Bandung, Refika Aditama, Bandung.

Starawaji, 2009, Corporate Social Responbility dalam Praktek di Indonesia, Elex Media Komputindo, Jakarta.

Supriyono, 2000, Sistem Pengendalian Manajemen, Universitas

Diponegoro, Semarang. 
Sugiyono dalam Prastowo, 2011, Metode Penelitian Kualitatif dalam Perspektif Rancangan Penelitian, Ar-Ruzz Media, Jogjakarta

Tantan, Hermansyah, 2009,DasarDasar Pengembangan Masyarakat Islam, Remaja Rosdakarya, Bandung.

Wahyudin, 2005, Petani dan Keterbelakangannya, Adhitya Bhakti, Bandung.

Widjaja, 2003, Otonomi Desa Merupakan Otonomi Bulat dan Utuh,Raja Grafindo Persada, Jakarta.

Winarto, Budi, 2012, Kebijakan Publik (Teori, Proses dan Studi Kasus), Media Pressindo, Yogyakarta.

\section{b. Jurnal}

Kesi Widjajanti, 2011, "Model Pemberdayaan

Masyarakat", Jurnal Ekonomi Pembangunan , Seri XII, Nomor 1.

\section{c. Peraturan Perundang- Undangan}

Undang-Undang Nomor 6 Tahun 2014 tentang desa

Undang-Undang Nomor 19 Tahun 2013 tentang perlindungan dan pemberdayaan petani

Undang-Undang Nomor 12 Tahun 2011 tentang pembentukan Peraturan PerundangUndangan.

Undang-Undang Nomor 10 Tahun 2004 tentang pembentukan Peraturan Daerah

Peraturan Pemerintah Nomor 72

Tahun 2005 tentang desa,
Peraturan Daerah Kabupaten Tulungagung Nomor 4 Tahun 2016 tentang perlindungan dan pemberdayaan petani

\section{d. Internet}

Arinda,2018, dalam http://farming.id/2018/05/berbagaipermasalahan-petani-indonesi-yangpenting-diperhatikan.html. di akses tanggal 09 april 2019

Rohmah Ermawati, 2019, dalam http://www.solopos.com/2019/03/ban jir-rendan-1.121-ha-lahan-padi-ditulungagung-kerugian-

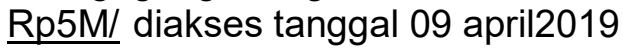

http://m.tulungagungtimes.com/201 9/03/hamparan-hijau-padi-menjadilautan-lumpur-warga-desaknormalisasi-sungai.html, diakses tanggal 13 april 2019

http://www.literaturbook.blogspot.co m/2014/12/sondang-othenklandasan-teori-efektivitas-menurutpara-ahli.html, diakses tanggal 05 april 2019 